\title{
Stromal myofibroblasts in focal reactive overgrowths of the gingiva
}

\begin{abstract}
Leonardo Silveira Damasceno Fernanda da Silva Gonçalves Edson Costa e Silva Elton Gonçalves Zenóbio Paulo Eduardo Alencar Souza Martinho Campolina Rebello Horta
\end{abstract}

Department of Dentistry, Pontifícia Universidade Católica de Minas Gerais, Belo Horizonte, MG, Brazil.
Declaration of Interests: The authors certify that they have no commercial or associative interest that represents a conflict of interest in connection with the manuscript.

Corresponding author:

Martinho Campolina Rebello Horta

E-mail: martinhohorta@pucminas.br

Received for publication on Feb 27, 2012

Accepted for publication on Apr 25, 2012
Abstract: Focal reactive overgrowths are among the most common oral mucosal lesions. The gingiva is a significant site affected by these lesions, when triggered by chronic inflammation in response to microorganisms in dental plaque. Myofibroblasts are differentiated fibroblasts that actively participate in diseases characterized by tissue fibrosis. The objective of this study was to evaluate the presence of stromal myofibroblasts in the main focal reactive overgrowths of the gingiva: focal fibrous hyperplasia $(\mathrm{FFH})$, peripheral ossifying fibroma (POF), pyogenic granuloma (PG), and peripheral giant cell granuloma (PGCG). A total of $10 \mathrm{FFHs}, 10$ POFs, 10 PGs, and 10 PGCGs from archival specimens were evaluated. Samples of gingival mucosa were used as negative controls for stromal myofibroblasts. Oral squamous cell carcinoma samples, in which stromal myofibroblasts have been previously detected, were used as positive controls. Myofibroblasts were identified by immunohistochemical detection of alpha smooth muscle actin ( $\alpha$-sma). Myofibroblast immunostaining was qualitatively classified as negative, scanty, or dense. Differences in the presence of myofibroblasts among FFH, POF, PG, and PGCG were analyzed using the Kruskal-Wallis test. Stromal myofibroblasts were not detected in FFH, POF, PG, or PGCG. Consequently, no differences were observed in the presence of myofibroblasts among FFH, POF, PG, or PGCG ( $p>0.05)$. In conclusion, stromal myofibroblasts were not detected in the focal reactive overgrowths of the gingiva that were evaluated, suggesting that these cells do not play a significant role in their pathogenesis.

Descriptors: Gingival Diseases; Gingival Overgrowth; Myofibroblasts; Immunohistochemistry.

\section{Introduction}

Focal reactive overgrowths are among the most common lesions of the oral mucosa. ${ }^{1}$ The gingiva is an important area affected by these lesions, ${ }^{1,2}$ primarily triggered by chronic inflammation in response to microorganisms in dental plaque..$^{2,3-7}$ These lesions are composed of one or more of the following connective tissue components:

- collagen,

- bone,

- endothelial cells, and

- multinucleated giant cells., ${ }^{1,2,7}$ 
The most common focal reactive overgrowths of the gingival connective tissue are:

- focal fibrous hyperplasia (FFH),

- peripheral ossifying fibroma (POF),

- pyogenic granuloma (PG), and

- peripheral giant cell granuloma (PGCG).,4,78

FFH, also known as irritation fibroma, is a focal reactive hyperplasia of fibroblasts with overproduction of collagen. ${ }^{2,5,7} \mathrm{POF}$ is a focal reactive hyperplasia of fibrous connective tissue presenting bone formation. ${ }^{7,9}$ PG is a focal reactive growth of granulation tissue with marked proliferation of endothelial cells and blood vessel formation. ${ }^{5,7}$ PGCG is a focal overgrowth composed of mononuclear and multinucleated giant cells. ${ }^{3,6,7}$

Myofibroblasts are differentiated fibroblasts that express alpha smooth muscle actin and that have intermediate characteristics of both classic fibroblasts and smooth muscle cells. ${ }^{10,11}$ Transdifferentiation by TGF- $\beta 1$ stimulation is its most common origin..$^{11,12}$ Myofibroblasts synthesize and degrade extracellular matrix components during inflammation and during the process of tissue repair and remodeling. ${ }^{10,11,13-15}$ Therefore, these cells actively participate in diseases characterized by the fibrosis of organs and tissues. ${ }^{14,15}$ Although the presence of myofibroblasts has been reported in hereditary gingival fibromatosis ${ }^{16}$ and drug-induced gingival hyperplasia, ${ }^{17,18}$ few studies have evaluated its presence in focal reactive overgrowths of the gingiva. ${ }^{19-22}$

Therefore, the aim of this study was to evaluate the presence of stromal myofibroblasts in the main focal reactive overgrowths of the gingiva ( $\mathrm{FFH}, \mathrm{PG}$, POF, and PGCG). Differences in the presence of myofibroblasts among FFH, POF, PG, and PGCG were also analyzed.

\section{Methodology Tissues and samples}

A total of 10 FFHs, 10 PGs, 10 POFs and 10 PGCGs, taken from archival formalin-fixed, paraffin-embedded specimens, were evaluated. This study was approved by the local ethics committee (CAAE - 0161.0.213.000-07).

\section{Immunohistochemistry}

Myofibroblasts were identified by the immunohistochemical detection of alpha smooth muscle actin ( $\alpha$-sma), a marker for myofibroblasts. Fourmicrometer sections from the paraffin-embedded samples were used. Tissue sections were dewaxed with xylene, hydrated using graded alcohols, and treated with $0.6 \% \mathrm{H}_{2} \mathrm{O}_{2}$ to eliminate endogenous peroxidase activity. Antigen retrieval was conducted by heating in a $0.01 \mathrm{M}$ citrate buffer $(\mathrm{pH}$ 6.0) for 30 minutes. Subsequently, an anti- $\alpha$-sma monoclonal antibody was used (clone 1A4, diluted 1:100; Dako Corporation, Carpinteria, USA). The LSAB+ kit (Dako Corporation, Carpinteria, USA) was used for the application of the biotinylated link antibody and of peroxidase-labeled streptavidin, according to the manufacturer's instructions. The reactive products were visualized by immersing the sections for $3 \mathrm{~min}$ in $0.03 \%$ diaminobenzidine solution, containing $2 \mathrm{mM} \mathrm{H}_{2} \mathrm{O}_{2}$. The sections were then counterstained with Mayer's hematoxylin, dehydrated, and mounted.

Normal vessels' smooth muscle immunoreactivity for $\alpha$-sma was used as an internal positive control. Samples of oral squamous cell carcinoma, showing numerous and densely arranged stromal myofibroblasts, were used as a positive control (Figure $1 \mathrm{~F}$ ). Samples of gingival mucosa were used as a negative control for myofibroblasts (Figure 1E). The negative control for $\alpha$-sma immunoreactivity was performed by omission of the primary antibody.

\section{Scoring of immunostaining results}

Alpha smooth muscle actin-positive stromal cells, showing cytoplasmic immunostaining, were considered to be myofibroblasts. Light microscopy was used to evaluate the immunohistochemical reactions. The myofibroblast immunostaining was qualitatively classified as negative (samples in which no stromal myofibroblasts were detected), scanty (samples showing sporadic stromal myofibroblasts), or dense (samples showing numerous and densely arranged stromal myofibroblasts).

\section{Statistical analysis}

The data were analyzed using BioEstat software, 

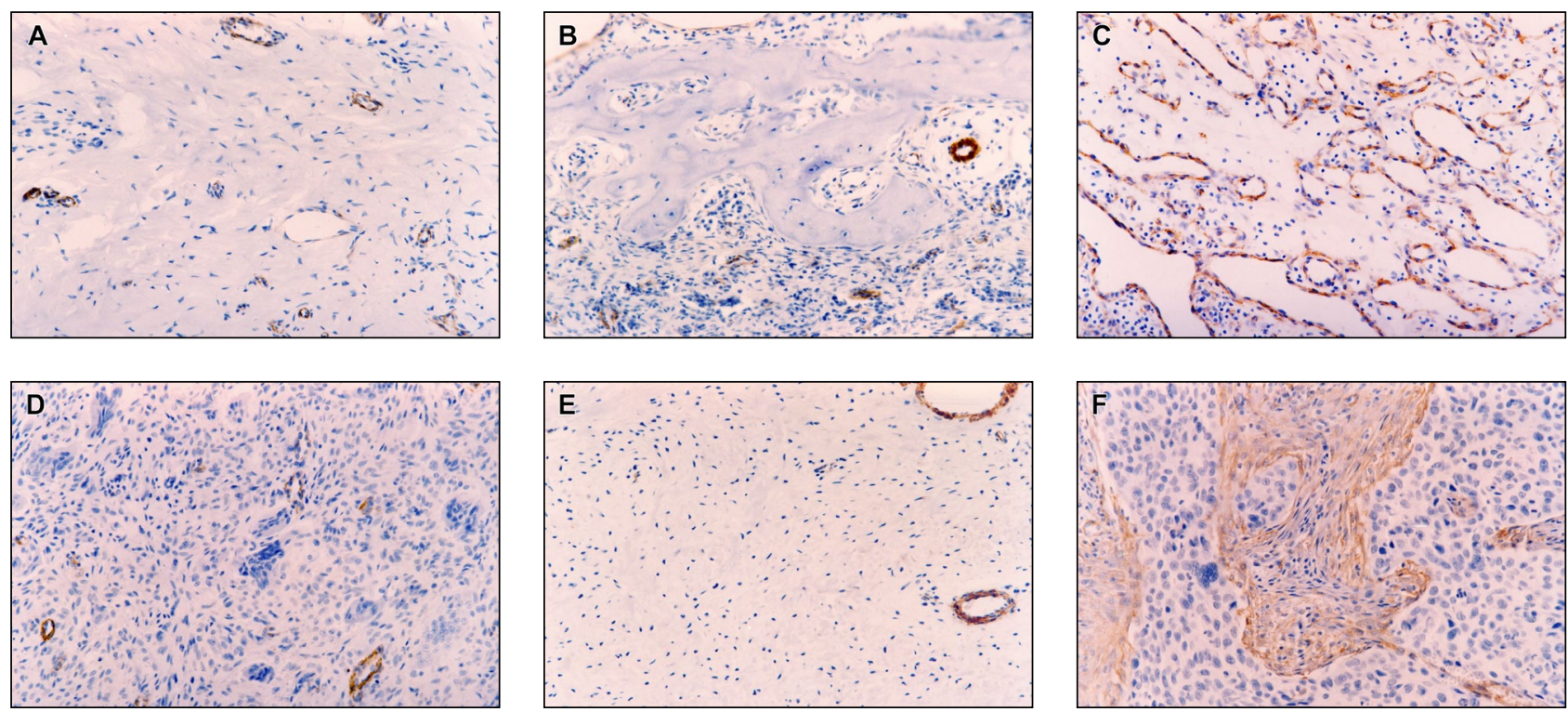

Figure 1 - Immunohistochemical reactivity for alpha smooth muscle actin ( $\alpha$-sma) (original magnification 200x): (A) focal fibrous hyperplasia (FFH); (B) peripheral ossifying fibroma (POF); (C) pyogenic granuloma (PG); (D) peripheral giant cell granuloma (PGCG); (E) gingival mucosa (negative control for myofibroblasts); (F) oral squamous cell carcinoma, showing numerous and densely arranged stromal myofibroblasts (positive control for myofibroblasts). FFH, POF, PG, PGCG and gingival mucosa ( $A, B, C, D$ and $E$ ) showing positivity only in the normal vessels' smooth muscle (internal control for $\alpha$-sma).

version 5.0 (Optical Digital Technology, Belém, Brazil). Differences in the presence of myofibroblasts among FFH, POF, PG, and PGCG were analyzed using the Kruskal-Wallis test. The level of significance was established at 5\%.

\section{Results} 1.

The results are illustrated in Table 1 and Figure

No stromal myofibroblasts were observed in FFH (Figure 1A), POF (Figure 1B), PG (Figure 1C), or PGCG (Figure 1D). Consequently, no differences were observed in the presence of myofibroblasts among FFH, POF, PG, or PGCG ( $p>0.05$ ).

\section{Discussion}

Myofibroblasts are differentiated fibroblasts that have morphologic and immunophenotypic features similar to those of smooth muscle cells. ${ }^{10,11}$ In addition to alpha smooth muscle actin, myofibroblasts show immunopositivity for vimentin, non-muscle myosin, and fibronectin. ${ }^{23}$ These cells show a spindle-cell or stellate-cell morphology, an eosinophilic cytoplasm and an abundant pericellular matrix..$^{23}$ Moreover, these cells display the typical ultrastruc-
Table 1 - Presence of stromal myofibroblasts in focal fibrous hyperplasia $(F F H)$, peripheral ossifying fibroma (POF), pyogenic granuloma (PG), and peripheral giant cell granuloma (PGCG).

\begin{tabular}{c|c|c|c|c}
\hline \multirow{2}{*}{ Samples } & \multicolumn{2}{|c|}{ Presence of myofibroblasts } & \multirow{2}{*}{ P-value $^{1}$} \\
\cline { 2 - 4 } & Negative & Scanty & Abundant & \\
\hline FFH $(n=10)$ & $10(100 \%)$ & 0 & 0 & \\
\cline { 1 - 3 } POF $(n=10)$ & $10(100 \%)$ & 0 & 0 & \multirow{2}{*}{$>0.05$} \\
\cline { 1 - 3 } PG $(n=10)$ & $10(100 \%)$ & 0 & 0 & \\
\hline PGCG $(n=10)$ & $10(100 \%)$ & 0 & 0 & \\
\hline
\end{tabular}

' $P$-value was obtained using the Kruskal-Wallis test.

tural features of secreting cells (a prominent rough endoplasmic reticulum and Golgi apparati producing secretion granules), as well as peripheral myofilaments, fibronexus junctions, and gap junctions. ${ }^{23}$ Myofibroblasts synthesize and secrete cytokines, inflammatory mediators, extracellular matrix proteins, matrix metalloproteinases and tissue inhibitors of matrix metalloproteinases (TIMPs). ${ }^{11-15}$

Due to their ability to secrete and degrade extracellular matrix components, myofibroblasts actively participate in the morphogenesis of tissues or organs, ${ }^{11}$ wound healing, ${ }^{10,11,13}$ fibrosis, ${ }^{14,15}$ and tumor 
invasion. ${ }^{24,25}$

Despite the relevance of myofibroblasts in diseases characterized by fibrosis, ${ }^{14,15}$ few studies have evaluated these cells in gingival overgrowths. ${ }^{16-20} \mathrm{In}$ granulation tissue, myofibroblasts undergo apoptosis after wound healing. ${ }^{11,13}$ However, during fibrosis, the continuous presence of TGF- $\beta 1$ should inhibit myofibroblast apoptosis, ${ }^{26}$ resulting in their accumulation, mainly in tissues presenting unremitting inflammation. ${ }^{11,13}$ As TGF- $\beta 1$ levels are 100fold greater in gingival inflammatory processes, such as periodontitis, ${ }^{27}$ and as gingival fibroblast transdifferentiation into myofibroblasts, through TGF- $\beta 1$ stimulation, has been reported, ${ }^{28}$ the evaluation of myofibroblasts in gingival inflammatory lesions is required. Therefore, this study aimed to evaluate the presence of myofibroblasts in the main focal reactive overgrowths of the gingiva.

FFH is characterized by the hyperplasia of fibroblasts with overproduction of collagen. ${ }^{2,5}$ POF is characterized by hyperplasia of fibrous connective tissue, nevertheless presenting bone formation. ${ }^{9}$ In this study, no myofibroblasts were detected in FFH or POF. These results are in agreement with those of previous reports ${ }^{20,21}$ and suggest that myofibroblasts are not significant in the pathogenesis of FFH or POF, despite their high fibroblast activity. This finding can be explained by the low TGF- $\beta 1$ levels in these lesions or by the presence of myofibroblast inhibitors, such as INF- $\gamma$, which can inhibit gingival myofibroblast transdifferentiation..$^{28}$

This is the first study evaluating myofibroblasts in PG, a focal reactive overgrowth with marked proliferation of endothelial cells and blood vessel formation. ${ }^{5}$ Despite its similarity to granulation tissue, an important site of myofibroblasts, ${ }^{11,13}$ these cells were not detected in any of the 10 PG samples that were evaluated.

Although previous reports have detected myofibroblasts in PGCG, ${ }^{19,21,22}$ no myofibroblasts were observed in the 10 PGCG samples evaluated in this study. This divergence is likely a consequence of methodological differences because one study used a histochemical marker for myosin, as well as electron microscopy, to detect myofibroblasts, ${ }^{19}$ and the other used immunohistochemical detection of HHF35, a muscle-actin-specific antibody. ${ }^{21}$ Nevertheless, another one of the studies ${ }^{22}$ detected myofibroblasts in PGCG using electron microscopy and immunohistochemical detection of alpha smooth muscle actin. An additional hypothesis is that myofibroblasts have been occasionally identified in PGCG because the former report evaluated only 5 samples, ${ }^{19}$ and the second study detected myofibroblasts in just 2 of 10 samples. ${ }^{21}$ In fact, myofibroblasts have also been sporadically detected in central giant cell granuloma, ${ }^{29}$ a lesion histologically similar to PGCG. Moreover, it is possible that myofibroblasts arise as cells in healing processes due to the ulceration of the primary lesions and not as a major player in the pathogenesis of these gingival overgrowths. Finally, it is important to emphasize that PGCG is composed of mononuclear and multinucleated giant cells $^{3,4,6}$ that show immunohistochemical markers of macrophages and osteoclasts. ${ }^{30}$

\section{Conclusion}

Stromal myofibroblasts were not detected in the focal reactive overgrowths of the gingiva that were evaluated, suggesting that these cells do not play a significant role in their pathogenesis.

\section{Acknowledgements}

This study was supported by grants from Conselho Nacional de Desenvolvimento Científico e Tecnológico - CNPq, Fundação de Amparo à Pesquisa do Estado de Minas Gerais - FAPEMIG, and Programa Institucional de Bolsas de Iniciação Científica (PROBIC) - PUC Minas, Brazil.

The authors wish to thank the invaluable technical assistance provided by Mrs. Maria Reni Gonçalves Moitinha. 


\section{References}

1. Stablein MJ, Silverglade LB. Comparative analysis of biopsy specimens from gingival and alveolar mucosa. J Periodontol. 1985 Nov;56(11):671-6.

2. Zhang W, Chen Y, An Z, Geng N, Bao D. Reactive gingival lesions: a retrospective study of 2439 cases. Quintessence Int. 2007 Feb;38(2):103-10.

3. Giansanti JS, Waldron CA. Peripheral giant cell granuloma: review of 720 cases. J Oral Surg. 1969 Oct;27(10):787-91.

4. Bhaskar SN, Cutright DE, Beasley JD, Perez B. Giant cell reparative granuloma (peripheral): report of 50 cases. J Oral Surg. 1971 Feb;29(2):110-5.

5. Kfir Y, Buchner A, Hansen LS. Reactive lesions of the gingival: a clinicopathological study of 741 cases. J Periodontol. 1980 Nov;51(11):655-61.

6. Bodner L, Peist M, Gatot A, Fliss DM. Growth potential of peripheral giant cell granuloma. Oral Surg Oral Med Oral Pathol Oral Radiol Endod. 1997 May;83(5):548-51.

7. Damasceno LS, Gonçalves FS, Costa e Silva E, Zenóbio EG, de Souza PEA, Horta MC. [Focal reactive overgrowths of the gingiva - a review of the literature]. Perionews. 2011 MarApr;5(2):169-76. Portuguese.

8. Buchner A, Calderon S, Ramon Y. Localized hyperplastic lesions of the gingiva: a clinicopathological study of 302 lesions. J Periodontol. 1977 Feb;48(2):101-4.

9. Buchner A, Hansen L. The histomorphologic spectrum of peripheral ossifying fibroma. Oral Surg Oral Med Oral Pathol. 1987 Apr;63(4):452-61.

10. Gabbiani G,Ryan GB, Majno G. Presence of modified fibroblasts in granulation tissue and their possible role in wound contraction. Experientia. 1971 May;27(5):549-50.

11. Tomasek JJ, Gabbiani G, Hinz B, Chaponnier C, Brown RA. Myofibroblasts and mechano-regulation of connective tissue remodelling. Nat Rev Mol Cell Biol. 2002 May;3(5):349-63.

12. Desmoulière A, Geinoz A, Gabbiani F, Gabbiani G. Transforming growth factor-beta 1 induces alpha-smooth muscle actin expression in granulation tissue myofibroblasts and in quiescent and growing cultured fibroblasts. J Cell Biol. 1993 Jul;122(1):103-11.

13. Hinz B. Formation and function of the myofibroblast during tissue repair. J Invest Dermatol. 2007 Mar;127(3):526-37.

14. Wight TN, Potter-Perigo S. The extracellular matrix: an active or passive player in fibrosis? Am J Physiol Gastrointest Liver Physiol. 2011 Dec;301(6):G950-5.

15. Sarrazy V, Billet F, Micallef L, Coulomb B, Desmoulière A. Mechanisms of pathological scarring: role of myofibroblasts and current developments. Wound Repair Regen. 2011 Sep;19(Suppl 1):10-5.

16. Bitu CC, Sobral LM, Kellermann MG, Martelli-Junior H, Zecchin KG, Graner E, et al. Heterogeneous presence of myofibroblasts in hereditary gingival fibromatosis. J Clin Periodontol. 2006 Jun;33(6):393-400.
17. Dill RE, Iacopino AM. Myofibroblasts in phenytoin-induced hyperplastic connective tissue in the rat and in human gingival overgrowth. J Periodontol. 1997 Apr;68(4):375-80.

18. Bullon P, Pugnaloni A, Gallardo I, Machuca G, Hevia A, Battino M. Ultrastructure of the gingiva in cardiac patients treated with or without calcium channel blockers. J Clin Periodontol. 2003 Aug;30(8):682-90.

19. Dayan D, Buchner A, David R. Myofibroblasts in peripheral giant cell granuloma. Light and electron microscopic study. Int J Oral Maxillofac Surg. 1989 Oct;18(5):258-61.

20. Lombardi T, Morgan PR. Immunohistochemical characterization of odontogenic cysts with mesenchymal and myofilament markers. J Oral Pathol Med. 1995 Apr;24(4):170-6.

21. Miguel MCC, Andrade ESS, Rocha DAP, Freitas RA, Souza LB. [Immunohistochemical expression of vimentin and HHF35 in giant cell fibroma, fibrous hyperplasia and fibroma of the oral mucosa.] J Appl Oral Sci. 2003 Mar;11(1):77-82. Portuguese.

22. Filioreanu AM, Popescu E, Cotrutz C, Cotrutz CE. Immunohistochemical and transmission electron microscopy study regarding myofibroblasts in fibroinflammatory epulis and giant cell peripheral granuloma. Rom J Morphol Embryol. 2009 Jul;50(3):363-8.

23. Eyden B. The myofibroblast: phenotypic characterization as a prerequisite to understanding its functions in translational medicine. J Cell Mol Med. 2008 Jan-Feb;12(1):22-37.

24. Kalluri R, Zeisberg M. Fibroblasts in cancer. Nat Rev Cancer. 2006 May; 6(5):392-401.

25. De Assis EM, Pimenta LG, Costa e Silva E, Souza PE, Horta MC. Stromal myofibroblasts in oral leukoplakia and oral squamous cell carcinoma. Med Oral Patol Oral Cir Bucal. Forthcoming 2012.

26. Zhang HY, Phan SH. Inhibition of myofibroblast apoptosis by transforming growth factor beta(1). Am J Respir Cell Mol Biol. 1999 Dec;21(6):658-65.

27. Steinsvoll S, Halstensen TS, Schenck K. Extensive expression of TGF- $\beta_{1}$ in chronically-inflamed periodontal tissue. J Clin Periodontol. 1999 Jun;26(6):366-73.

28. Sobral LM, Montan PF, Martelli-Junior H, Graner E, Colleta RD. Opposite effects of TGF-beta1 and IFN-gamma on transdifferentiation of myofibroblast in human gingival cell cultures. J Clin Periodontol. 2007 May;34(5):397-406.

29. Vered M, Nasrallah W, Buchner A, Dayan D. Stromal myofibroblasts in central giant cell granuloma of the jaws cannot distinguish between non-aggressive and aggressive lesions. J Oral Pathol Med. 2007 Sep;36(8):495-500.

30. Tiffee JC, Aufdemorte TB. Markers for macrophage and osteoclast lineages in giant cell lesions of the oral cavity. J Oral Maxillofac Surg. 1997 Oct;55(10):1108-12. 